sense is not exceptional. But given the rise of intra-state cases of violent conflicts in recent decades, now is neither the time for academic networking, nor for the application of ideal theory, but for interdisciplinary cooperation and the courage to reassess traditional premises of political liberalism. By trying to reassess the practical success of liberal multiculturalism, Multicultural Odysseys is making a step in such a direction.

\title{
References
}

Chwaszcza, Christine (2007) Moral Responsibility and Global Justice: A Human Rights Approach. Baden-Baden: Nomos.

Finnemore, Martha (2003) The Purpose of Intervention. Ithaca, NY/London: Cornell University Press.

Ignatieff, Michael (2003) 'State Failure and Nation-building', in J.L. Holzgrefe and

Robert O. Keohane (eds) Humanitarian Intervention, pp. 299-321. Cambridge:

Cambridge University Press.

Paris, Roland (2004) At War's End: Building Peace after Civil Conflict. Cambridge: CUP.

Rawls, John (1971) A Theory of Justice. Cambridge, MA: Harvard University Press.

CHRISTINE CHWASZCZA is Professor of social and political theory in the Department of Political and Social Sciences, at the European University Institute. Address: European University Institute, Via dei Roccettini 9, I-50014 San Domenico di Fiesole (FI), Italy. [email: Christine.Chwaszcza@eui.eu]

\section{Kymlicka's odyssey - lured by norms into the rocks of politics}

\section{GWENDOLYN SASSE}

University of Oxford, UK

Will Kymlicka has written another major study of multiculturalism that will keep the academic community occupied for years to come and attract the attention of policy makers. The title of his new book - Multicultural Odysseys - evokes the image of long and nightmarish journeys, though there is no apparent Odysseus-type protagonist in the story he tells. The book is written in the style of an extended essay and places Kymlicka's 
normative view of minority rights in the context of European and, to some extent, global politics. While Kymlicka has long moved beyond 'pure' political philosophy, compared to previous publications he now incorporates a much larger slice of the 'real' world of human and minority rights. As the balance of his analysis now tilts towards the latter, the conceptual and empirical problems inherent in this endeavour have become more obvious. Normative theory and empirical research are always difficult to marry. While not rooted in original empirical research as such, this book is clearly driven by an empirical concern that the author addresses with a sense of urgency. For Kymlicka believes that the window of opportunity for establishing an international environment favourable to the promotion of 'liberal multiculturalism', which opened up in the last decade of the 20th century, appears to be closing. The globalization of multiculturalism has become unstuck before it could really take off. In the introduction, Kymlicka refers to the increasing internationalisation of state-minority relations and the global diffusion of multiculturalism as a new framework for reforming those relations' (p. 3). By the time he reaches the conclusion, pessimism prevails: 'the time for a real push on minority rights may have passed' (p. 315). Can we be so categorical about the developments in the international system? In fact, Kymlicka, it seems to me, overstates the 'dramatic shift' towards a European or international consensus on national minority rights, including territorial autonomy as a best practice, in the early 1990s. Equally, he overestimates the international shift against such minority rights by the turn of the century.

The book makes for a powerful read precisely because the combination of a normative starting point, and an empirical driving force reveals the author's activist stance. The promotion of any political agenda, however, necessarily involves a selective reading of the world around you. Kymlicka's selectivity, which must be deliberate rather than accidental, manifests itself in two ways in this book: in a selective description of European or international declarations, recommendations and examples of 'hard' and 'soft' law, and in a selective engagement both with the empirical research on his cases (groups, countries, regions, international institutions) and, more importantly, with conceptual and empirical challenges to his arguments. What does not fit the 'norm' or argument is left out altogether, or at best marginalized. For example, he emphasizes the importance of the 1990 OSCE Copenhagen Declaration and resolutions of the Parliamentary Assembly of the Council of Europe, which mention territorial autonomy for national minorities, but he glosses over the disputes accompanying these documents and modifications. Kymlicka's previous work on minorities has been a foundation for the development of new debates on the issue, but his claim to start a long overdue debate with this book, where there isn't one at the moment, is a misrepresentation of the current state of affairs in the study and policy making on national minorities and, in 
particular, immigrants. The problem is that the newer strands of this debate are pointing in a direction that goes against the gist of some of Kymlicka's arguments.

In Multicultural Odysseys, Kymlicka repeats a distinction he has made before: he differentiates between the needs and rights of indigenous peoples, national minorities and immigrants. Though convincingly pointing to the need to reconsider the categories we use to label and define groups or group rights and the assumptions they are built upon, he does not engage critically with his own previously established categories (Kymlicka, 1995). That not all national minorities demand self-government, let alone territorial autonomy, is a criticism Kymlicka has heard many times. However, he once again only addresses this in passing and, for the most part, focuses on familiar cases that involve a claim to autonomy. In fact, the demands of national minorities and immigrants and the actual policy responses to these demands are not always as different as Kymlicka implies, as his own examples of immigrants' 'polyethnic rights' (e.g. language, religion) demonstrate. Similarly, the implied distinction between 'old' and 'new' minorities is flawed. It creates the impression of clear-cut and static temporal categories where, in fact, the boundaries are much fuzzier (Boswell, 2003; Sasse and Thielemann, 2005). The questioning of the logic underpinning these distinctions is not only a conceptual issue, as the increasing overlap of 'old' and 'new' minority issues in the discourse of international institutions, such as the OSCE or the Council of Europe, demonstrates. The Advisory Council in charge of the monitoring process that goes with the Council of Europe's Framework Convention for the Protection of National Minorities (FCNM) has a record of questioning the definitions or lists of "national minorities' given by the signatories. Kymlicka fears that any widening of the definitions and exclusive lists of named groups in the operation of the FCNM will gradually undermine the principle of national minority rights. A closer look at the comments of the Advisory Committee, however, reveals that its main function has been as a check on politically motivated omissions and narrow definitions. These conceptual and empirical challenges are suspect to Kymlicka who fears that the essence of specifically targeted national minority rights is being watered down as a result of the widening of group definitions. Here the normative drive reveals its essentialist core. It would have been more rewarding if Kymlicka had revisited his own arguments more critically and tackled criticism or alternative interpretations head-on.

Kymlicka rightly identifies a mixture of European security concerns in the context of post-communist wars and conflict potential as the starting point of the normative shift towards the international promotion of multiculturalism in the early 1990s. Thus, he acknowledges that a set of 'real' policy issues tied to security concerns brought minority rights on to the international political agenda. He simultaneously presents the 
'securitisation' of minority rights as a problem undermining norms rooted in the principles of justice. Thus, we are left with a conundrum: security concerns made international and, in particular, European institutions single out minority protection as a means of conflict prevention and conflict management in the 1990s, but in Kymlicka's view these concerns also contain the seeds of the demise of a meaningful norm of minority rights. The empirical reality of politics spells out both the norm's relevance and its potentially fickle resonance. The assumption that 'security trumps justice' (p. 191) is too simplistic. For, as I have argued elsewhere, the recognition of an intricate 'security-rights-nexus' might be a more fruitful conceptualization than an 'either-or' choice between security and justice (Sasse, 2005a).

A point that Kymlicka made so well in previous writings is at the heart of his definition of 'liberal multiculturalism': minority rights can be reconciled with the fundamentals of liberalism, as a member of a minority group has to make a choice as an individual whether or not to be associated with this group and claim rights by reference to this group. This logic nicely cuts through the endless debates about individual vs. group rights. In his new book, Kymlicka builds on this earlier argument by pointing to the need to distinguish further between 'generic' minority rights and 'specifically targeted' minority rights. This is both a useful conceptual clarification and policy recommendation, but it does not per se amount to a new framework of analysis. Kymlicka knows that the codification of targeted minority rights is politically unrealistic and says as much in the conclusion.

To me, the limitations of Kymlicka's arguments become most obvious in his long chapter on 'the European experiment', the main testing ground because of the intensity of multilayered international institutions with a remit touching on minority issues. It is easy to find factual inaccuracies in a study of this scope. However, some of these are more critical than others. Referring to the 'ethnic Russian minority' in Estonia and Latvia misses the point that the minority at stake is, in fact, a loose linguistic one (Russophones) rather than a clearly defined national minority, and at least partly explains its lack of political mobilization. Calling the EU an 'international organization' and treating it as such has implications for the argument presented. Given that the EU has become a more supranational than an international organization, EU law has a much more direct and comprehensive effect on the member states. Therefore, the EU's quite elaborate antidiscrimination acquis should have been included in Kymlicka's discussion. Though not specifically targeting minority rights, many of the nondiscrimination provisions touch on minority-related issues, and these recent developments in EU law qualify Kymlicka's statement about a shift away from the principle of minority protection. Moreover, the EU's eastward enlargement and the EU's increasing involvement in conflict management provide a rich empirical setting to analyse the scope and limitations of international involvement. With regard to the former, Kymlicka refers to the 
inclusion of 'minority rights' (p. 4, n. 26) in the EU's Copenhagen criterion, though the actual wording of the condition is more cautious, asking potential member states to safeguard the 'respect for and the protection of minorities', while deliberately avoiding a reference to 'rights' or 'national minorities'. In a footnote, Kymlicka refers to the late addition of a weak reference to minorities in the draft EU Constitution (p. 235, n. 73). This reference brought EU law in line with the organized formulation of the first Copenhagen criterion. Kymlicka detects a change for the worse where, in fact, little has changed in rhetoric or practice. Although Kymlicka refers to the inconsistencies involved in the enforcement of the EU's minority condition, the evidence and ongoing debates about the effectiveness of the EU's conditionality are only alluded to, despite their significance for his overall argument (Kelley, 2004; Sasse, 2005b; Hughes, 2005).

With regard to the conflicts in former Yugoslavia and the former Soviet Union, Kymlicka's category of 'homeland minorities' wanting to re-establish self-government does not accurately capture the nature of these conflicts. He does not discuss the role of institutional legacies that shaped the outbreak and dynamics of conflict. Many of the regions he refers to, such as Abkhazia, South Ossetia or Kosovo, enjoyed a degree of autonomy before the collapse of communism and were reacting to the threat of changes to their constitutional status that came from hegemonic nationalisms during the transition. When de facto and de jure autonomy re-emerge amidst attempts to resolve conflicts, this principle is not new, and it fits within a socialist tradition of managing nationalism rather than being a normative principle as such. Similarly, the institutional legacy and the experience of state disintegration in the former Yugoslavia and the Soviet Union have shaped the reluctance towards autonomy across Eastern Europe rather than the 'fear' that national minorities 'will collaborate with enemies of the state', i.e. with kin-states (p. 183). Kymlicka posits that two preconditions make the accommodation of minority demands, especially the claim to autonomy, more unlikely in transition states: the absence of reliable human rights protection and the ongoing securitization of ethnic relations (p. 182). A closer look at the empirical evidence from Central and Eastern Europe, however, calls this conclusion into question: precisely at the time when transition states with sizeable national minorities - for example Slovakia, Romania or Bulgaria - were consolidating their democracies, the respective ethno-political parties dropped or moderated their claims to territorial autonomy. The sustained significance of ethnic parties in several Central and Eastern European countries points to an alternative channel for minority demands and puts Kymlicka's statement in perspective that, for example, the Hungarian minority in Slovakia is 'relatively powerless in relation to the overwhelming ethnic Slovak majority in the country' (p. 185).

Kymlicka's first-hand experience with the many groups and countries around the world has been, as he says in the introduction, through 
workshops and advisory groups on the accommodation of diversity, multiculturalism and minority rights. Extrapolating the global circulation of these ideas from selected groups of like-minded academics or policy makers runs the risk of overestimating the normative shift in the first place. Similarly, the increasing marginalization of national minority rights also appears exaggerated. The normative approach breeds high expectations and great disappointments. Kymlicka's biggest contribution is to forcefully point to the 'minefield of conceptual confusions, moral dilemmas, unintended consequences, legal inconsistencies and political manipulation' (p. 8) tied to the rights of minorities.

\section{References}

Boswell, Christina (2003) European Migration Policies in Flux: Changing Patterns of Inclusion and Exclusion. Chatham House Papers, Oxford: Blackwell.

Geddes, Andrew (2002) The Politics of Migration and Immigration in Europe. London: SAGE.

Hughes, James (2005) “"Exit” in Deeply Divided Societies: Regimes of Discrimination in Estonia and Latvia and the Potential for Russophone Migration', Journal of Common Market Studies 43(4): 739-62.

Kelley, Judith (2004) Ethnic Policies in Europe: The Power of Norms and Incentives. Princeton University Press.

Kymlicka, Will (1995) Multicultural Citizenship: A Liberal Theory of Minority Rights. Oxford: Oxford University Press.

Sasse, Gwendolyn and Thielemann, Eiko (2005) 'A Research Agenda for the Study of Migrants and Minoritiess in Europe', Journal of Common Market Studies 43(4): 655-71.

Sasse, Gwendolyn (2005a) 'Securitization or Securing Rightss? Exploring the Conceptual Foundations of Policies towards Minorities and Migrants in Europe', Journal of Common Market Studies 43(4): 673-93.

Sassse, Gwendolyn (2005b) 'EU Conditionality and Minority Rights: Translating the Copenhagen Criterion into Policy', EUI Working Paper No. 2005/16.

GWENDOLYN SASSE is a Professional Fellow at Nuffield College and Reader in Politics in the Department of Politics and International Relations at the University of Oxford. Address: Nuffield College, University of Oxford, New Road, Oxford OX1 1NF, UK. [email: Gwendolyn.Sasse@ nuffield.ox.ac.uk] 